\title{
Hubungan Gaya Kepemimpinan Kepala Ruangan Dan Motivasi Kerja Dengan
}

\section{Kinerja Perawat Di Ruang Rawat Inap RS AN-NISA Tangerang}

\author{
Alpan Habibi ${ }^{1}$, Ummi Giyanti ${ }^{2}$, Nining Sriningsih ${ }^{3}$ \\ ${ }^{1,2}$ Fakultas Ilmu Kesehatan Universitas Muhammadiyah Tangerang \\ ${ }^{3}$ RSU KabupatenTangerang
}

Email: alpanhabibi15@gmail.com

\begin{abstract}
Abstrak
Di rumah sakit tenaga keperawatan merupakan sumber daya manusia terbanyak dari segi jumlah dan paling lama berinteraksi dengan klien. Standar praktik keperawatan meliputi standar asuhan dan standar kinerja profesional yang dipakai sebagai evaluasi dalam menilai asuhan keperawatan yang dilakukan oleh perawat. Kinerja atau prestasi kerja berasal dari kata job perfomance (prestasi kerja atau prestasi sesungguhnya yang pernah dicapai seseorang). Faktor yang dapat mempengaruhi kinerja, yaitu faktor individu : kemampuan, keterampilan, latar belakang keluarga, pengalaman kerja, tingkat sosial dan demografi seseorang; faktor psikologis: persepsi, peran, sikap, kepribadian, motivasi, dan kepuasan kerja; faktor organisasi: struktur organisasi, desain pekerjaan, kepemimpinan. Mendapatkan kinerja yang baik dari perawat, dibutuhkan seorang pemimpin yang dapat memahami kebutuhan perawat serta mampu memberikan lingkungan kerja yang baik untuk membuat perawat merasa termotivasi. Penelitian ini bertujuan untuk mengetahui hubungan gaya kepemimpinan kepala ruangan dan motivasi kerja dengan kinerja perawat di ruang rawat inap $R S$ AN-NISA Tangerang. Desain penelitian yang digunakan korelasional kuantitatif dengan pendekatan cross sectional. Sampel dalam penelitian ini adalah perawat pelaksana di ruang rawat inap RS AN-NISA Tangerang menggunakan teknik purposive sampling dengan jumlah 83 responden. Teknik analisa menggunakan uji Chi square. Didapatkan hasil bahwa gaya kepemimpinan yang paling dominan di ruang rawat inap RS AN-NISA Tangerang adalah gaya demokratis (48,2\%). Terdapat hubungan antara gaya kepemimpinan kepala ruangan dengan kinerja perawat (p.value $=0,033$ ) dan terdapat hubungan antara motivasi kerja dengan kinerja perawat (p.value=0,019). Diharapkan penelitian ini dapat dijadikan bahan evaluasi rumah sakit terkait gaya kepemimpinan kepala ruangan, motivasi kerja dan kinerja perawat pelaksana untuk dapat mempertahankan maupun meningkatkan kinerja perawat.
\end{abstract}

Kata Kunci: Gaya Kepemimpinan; Motivasi Kerja; Kinerja Perawat

Rujukan artikel penelitian:

Habibi, A. Giyanti, U. Sriningsih, N. (2019). Hubungan Gaya Kepemimpinan Kepala Ruangan Dan Motivasi Kerja Dengan Kinerja Perawat Di Ruang Rawat Inap RS ANNISA Tangerang. Jurnal Ilmiah Keperawatan Indonesia. Vol. 2 (2): 65-80 


\title{
Relationship Among Room Head's Leadership Style and Work Motivation With Nurses' Performance in Inpatient Room at AN-NISA Hospital Tangerang
}

\begin{abstract}
In the hospital, nursing staff are the greatest number of hospital human resource and the longest staff who interact with clients. Nursing practice standards, include the standard of care and the professional performance standard that are use as evaluations in assessment nursing care who carry out by nurses. Performance or work performance comes from job performance word (work performance or real achievement someone has ever achieved). The factors that can affect on someone performance, are individual factors: abilities, skills, family background, work experience, social level and demography factor; psychological factors: perception, role, attitude, personality, motivation, and job satisfaction; organizational factors: organizational structure, job design, and leadership. To getting nurses with good performance, hospital need a leader who can understand the nurses' necessary and can provides good environmental assistance to make nurses feel motivated. This study aims to determine the relationship between room head's leaderschip style and work motivation in the inpatient room of AN-NISA Hospital, Tangerang. The research design used is a quantitative correlation with a cross-sectional approach. The sample in this study is organizer nurses in the inpatient room of AN-NISA Hospital in Tangerang and using purposive sampling technique with 83 respondents. Analysis technique using Chi-square test. The results showed that the dominant style of leadership in inpatient room of AN-NISA Hospital Tangerang is democratic style (48.2\%). There is a relationship between the room head's leadership style and the performance of nurses (p.value $=0.033$ ) and there is a relationship between work motivation and nurse performance ( $p$. Value $=0.019)$. It is hoped that this research can be used as a material for evaluating hospitals regarding the leadership style of the head of the room, work motivation and performance of the nurse nurses to be able to maintain and improve the performance of nurses.
\end{abstract}

Keywords: Leadership Style; Work Motivation; Nurse Performance 


\section{PENDAHULUAN}

Rumah sakit merupakan salah satu bentuk sarana kesehatan, baik yang diselenggarakan oleh pemerintah dan atau masyarakat yang berfungsi untuk melakukan upaya pelayanan kesehatan. Keberhasilan suatu rumah sakit dalam menjalankan fungsinya ditandai dengan adanya peningkatan mutu pelayanan di rumah sakit. Mutu rumah sakit dipengaruhi oleh beberapa faktor. Faktor yang paling dominan adalah sumber daya manusia (Calundu, 2018:77). Sumber daya manusia adalah tenaga kesehatan profesi, tenaga kesehatan non profesi dan tenaga kesehatan pendukung atau penunjang kesehatan yang terlibat dan bekerja serta mengabdi. Salah satu yang termasuk sumber daya manusia di kesehatan adalah perawat (Kepmenkes, 2009). Tenaga keperawatan di rumah sakit adalah ujung tombak pelayanan kesehatan, dimana tenaga keperawatan bekerja selama 24 jam mendampingi dan memonitor kesehatan pasien secara terus-menerus dan berkesinambungan untuk memberikan asuhan keperawatan yang komperehensif dan profesional (Sondang 2003 dalam Calundu 2018:77).

Persatuan Perawat Nasional Indonesia (PPNI) pada tahun 2010 telah mensahkan standar profesi keperawatan sebagaimana tercantum dalam pasal 24 ayat (2) UU No. 36 tahun 2009 yang terdiri dari standar kompetensi dan standar praktik keperawatan. Standar praktik merupakan komitmen perawat dalam melindungi masyarakat terhadap praktik yang dilakukan oleh anggota profesi. Standar praktik keperawatan meliputi standar asuhan dan standar kinerja profesional yang dipakai sebagai evaluasi dalam menilai asuhan keperawatan yang dilakukan oleh perawat.

Kinerja atau prestasi kerja berasal dari kata job perfomance (prestasi kerja atau prestasi sesungguhnya yang pernah dicapai seseorang). Pengertian kinerja (prestasi kerja) adalah hasil kerja secara kualitas dan kuantitas yang dicapai oleh seorang pegawai dalam melaksanakan tugasnya sesuai dengan tanggung jawab yang diberikan kepadanya. Menurut Gibson (1997) dalam Nursalam (2015:125) faktor yang dapat mempengaruhi kinerja, yaitu faktor individu : kemampuan, keterampilan, latar belakang keluarga, pengalaman kerja, tingkat sosial dan 
demografi seseorang; faktor psikologis: persepsi, peran, sikap, kepribadian, motivasi, dan kepuasan kerja; faktor organisasi: struktur organisasi, desain pekerjaan, kepemimpinan, sistem penghargaan (reward system).

Menurut Stoner dan Freeman (1995) dalam Nursalam (2011:85), menyebutkan, motivasi adalah karakteristik psikologi manusia yang memberi kontribusi pada tingkat komitmen seseorang. Sehingga dengan motivasi, seseorang bisa menyalurkan dan mempertahankan tingkah laku manusia untuk suatu tujuan tertentu. Motivasi pada dasarnya adalah proses untuk mempengaruhi seseorang agar melakukan sesuatu yang kita inginkan. Dengan kata lain dorongan dari luar terhadap seseorang agar mau melakukan sesuatu. Keberhasilan organisasi (manajemen) dalam mempertahankan perawat terbaik yang dimiliki tidak dicapai dengan cara mudah. Hal tersebut hanya dapat terjadi berkat kepiawaian manajemen dalam memahami kebutuhan perawat dan kemampuan mereka untuk menciptakan lingkungan kerja yang kondusif yang dapat membuat perawat merasa termotivasi secara internal. Gaya kepemimpinan merupakan ciri khas yang dimiliki seseorang dalam menjalankan perannya sebagai seorang pemimpin, gaya kepemimpinan secara langsung maupun tidak langsung mempunyai pengaruh yang positif terhadap peningkatan produktivitas kerja karyawan.

Berdasarkan hasil observasi di beberapa ruang rawat inap terlihat bahwa antara kepala ruangan dengan perawat pelaksana sangat akrab, harmonis tetap saling menghormati dan sesuai dengan perannya masing-masing. Maka dari itu, peneliti tertarik untuk mengambil judul "Hubungan Gaya Kepemimpinan Kepala Ruangan Dan Motivasi Kerja Dengan Kinerja Perawat Di Ruang Rawat Inap RS AN-NISA Tangerang" untuk mengetahui hubungan gaya kepemimpinan kepala ruangan dengan kinerja perawat dan motivasi kerja dengan kinerja perawat di ruang rawat inap RS AN-NISA Tangerang.

\section{BAHAN DAN METODE}

Penelitian ini dilakukan di Ruang Rawat Inap RS AN-NISA Tangerang pada bulan Juli 2019. Jenis penelitian ini merupakan korelasional kuantitatif dengan 
pendekatan cross sectional. Populasi dalam penelitian ini adalah seluruh perawat pelaksana di ruang rawat inap yang berjumlah 104 orang dari 7 ruang rawat inap yang ada di RS AN-NISA Tangerang. Teknik pengambilan sampel yang digunakan purposive sampling dengan kriteria yang sudah ditentukan. Maka didapatkan responden berjumlah 83 orang.

Instrumen yang digunakan pada penelitian ini yaitu lembar kuesioner. Analisa data yang digunakan pada penelitian ini adalah analisa univariat dan analisa bivariat. Analisa univariat untuk mengetahui karakteristik perawat pelaksana yang menjadi responden, meliputi: nama, umur, jenis kelamin, pendidikan, lama kerja serta untuk mengidentifikasi gaya kepemimpinan kepala ruangan, motivasi kerja, dan kinerja perawat. Analisa bivariat untuk mengetahui hubungan gaya kepemimpinan kepala ruangan dengan kinerja perawat dan hubungan motivasi kerja dengan kinerja perawat. Analisa bivariat dalam penelitian ini menggunakan uji Chi-Square.

\section{HASIL DAN BAHASAN}

\section{A. Analisa Univariat}

1. Karakteristik Responden

Tabel 1. Distribusi Karakteristik Responden Perawat Pelaksana Di Ruang Rawat Inap RS AN-NISA Tangerang $(n=83)$

\begin{tabular}{|c|c|c|c|}
\hline No. & Variabel & Frekuensi & Presentasi $(\%)$ \\
\hline \multirow[t]{6}{*}{1} & Usia & & \\
\hline & - Remaja akhir & 34 & 41,0 \\
\hline & - Dewasa awal & 47 & 56,6 \\
\hline & - Dewasa akhir & 2 & 2,4 \\
\hline & - Lansia awal & 0 & 0 \\
\hline & Jumlah & 83 & $100 \%$ \\
\hline \multirow[t]{4}{*}{2} & Jenis Kelamin & & \\
\hline & - Laki-laki & 17 & 20,5 \\
\hline & - Perempuan & 66 & 79,5 \\
\hline & Jumlah & 83 & $100 \%$ \\
\hline \multirow[t]{6}{*}{3} & Pendidikan Terakhir & & \\
\hline & $-\quad S 2$ & 0 & 0 \\
\hline & - Ners & 81 & 97,6 \\
\hline & $-\quad \mathrm{S} 1$ & 0 & 0 \\
\hline & - D-III & 2 & 2,4 \\
\hline & Jumlah & 83 & $100 \%$ \\
\hline \multirow[t]{2}{*}{4} & Lama Bekerja & & \\
\hline & $-\quad \leq 3$ tahun & 33 & 39,8 \\
\hline
\end{tabular}




\begin{tabular}{ccc}
$-\quad>3$ tahun & 50 & 60,2 \\
\hline Jumlah & $\mathbf{8 3}$ & $\mathbf{1 0 0 \%}$ \\
\hline Sumber: Pengolahan Data Kuesioner, Juli 2019 &
\end{tabular}

\section{a. Usia}

Penelitian ini menggunakan kategori umur menurut Depkes RI (2009) yaitu: masa remaja akhir 17-25 tahun, masa dewasa awal 2635 tahun, masa dewasa akhir 36-45 tahun, masa lansia awal 46-55 tahun. Berdasarkan hasil penelitian yang dilakukan pada 83 responden melalui kuesioner didapatkan bahwa sebagian besar responden berada pada rentang usia Dewasa Awal (26-35) 47 responden (56,6\%). Menurut Wahyudi (2010) dalam Darmayanti (2015) Usia dapat mempengaruhi kinerja ketika usia terus bertambah, hal ini berdampak pada kecepatan, kecekatan, kekuatan dan koordinasi akan terjadi penurunan. Hal ini sesuai dengan penelitian yang dilakukan oleh Librianty (2018) tentang Hubungan Motivasi dengan Kinerja Perawat Pelaksana di UPTD Kesehatan Tapung Kab. Kampar didapatkan hasil bahwa dari 30 responden sebagian besar berada pada rentang usia 25-35 tahun sebanyak 19 responden $(63,3 \%)$.

\section{b. Jenis Kelamin}

Berdasarkan hasil penelitian didapatkan hasil bahwa dari 83 responden mayoritas berjenis kelamin perempuan sebanyak 66 (79,5\%). Menurut Evans (1997) dalam Darmayanti (2015) di Indonesia perawat lebih di dominasi oleh wanita karena keperawatan identik dengan feminisme dimana sifat tersebut sangat membantu dalam memberikan asuhan keperawatan di ruang perawatan karena 
berhubungan dengan penerapan konsep caring dan komunikasi pada pasien. Selain itu, wanita lebih memperhatikan ketelitian dalam melakukan tindakan sehingga resiko terjadinya insiden human error dapat ditekan dan di minimalisir. Hal ini sesuai dengan hasil penelitian yang dilakukan oleh Librianty (2018) dengan judul Hubungan Motivasi dengan Kinerja Perawat Pelaksana di UPTD Kesehatan Tapung Kab. Kampar bahwa dari 30 responden mayoritas berjenis kelamin perempuan sebanyak 18 responden $(60,0 \%)$.

\section{c. Pendidikan Terakhir}

Berdasarkan hasil penelitian didapatkan hasil pendidikan perawat di ruang rawat inap RS AN-NISA terbanyak adalah Ners 81 orang $(97,6 \%)$. Hal ini sejalan dengan penelitian yang dilakukan oleh Nurhidayah (2018) dengan judul Faktor-Faktor Yang Berhubungan Dengan Kinerja Perawat di Ruang Perawatan RSUD Kota Makassar didapatkan hasil bahwa dari 49 responden, 26 responden $(63,1 \%)$ berpendidikan profesi Ners. Hal ini sesuai dengan penelitian yang dilakukan oleh Idris, et al (2017) dengan judul Hubungan Gaya Kepemimpinan Kepala Ruangan Terhadap Kinerja Perawat Dalam Melaksanakan Asuhan Keperawatan di Ruang Rawat Inap RSUD Labuang Baji Makassar didapatkan hasil dari 68 responden mayoritas berpendidikan Profesi Ners sebanyak 45 responden (66,2\%). Menurut Ibid (2005) dalam Darmayanti (2015), jenjang pendidikan sarjana lebih memiliki kemampuan untuk menggabungkan antara basic knowledge dan praktek dengan mempertimbangkan rasional tindakan yang diberikan.

\section{d. Lama Kerja}

Menurut Wahyudi (2010) dalam Darmayanti (2015), Lama kerja merupakan rentang waktu yang telah dilewati oleh seorang pekerja atau karyawan didalam menjalankan aktivitas pekerjaanya. Lama kerja selalu dihubungkan dengan pengalaman seseorang dalam bidangnya walaupun tidak selalu mencerminkan baik. Penelitian ini 
menggunakan kategori lama kerja menurut Handoko (2007): lama kerja kategori baru $\leq 3$ tahun dan lama kerja kategori lama > 3 tahun. Berdasarkan hasil penelitian yang dilakukan di ruang rawat inap RS AN-NISA Tangerang kepada 83 responden menunjukkan bahwa mayoritas responden sudah bekerja lebih dari 3 tahun (> 3 tahun) sebanyak 50 orang $(60,2 \%)$. Hal ini sejalan dengan penelitian yang dilakukan oleh Nurhidayah (2018) dengan judul Faktor-Faktor Yang Berhubungan Dengan Kinerja Perawat di Ruang Perawatan RSUD Kota Makassar didapatkan hasil bahwa dari 49 responden, 31 responden sudah bekerja $>3$ tahun $(63,3 \%)$.

\section{Gaya Kepemimpinan Kepala Ruangan}

Tabel 2. Gaya Kepemimpinan Kepala Ruangan di Ruang Rawat Inap RS AN-NISA Tangerang $(\mathrm{n}=83)$

\begin{tabular}{|c|c|c|c|}
\hline No. & Variabel & Frekuensi & Presentasi $(\%)$ \\
\hline \multirow[t]{2}{*}{1} & - $\quad$ Tidak otoriter & 36 & 43,4 \\
\hline & - Otoriter & 47 & 56,6 \\
\hline \multicolumn{2}{|r|}{ Jumlah } & 83 & $100 \%$ \\
\hline \multirow[t]{2}{*}{2} & - Tidak Laissez Faire & 54 & 65,1 \\
\hline & - $\quad$ Laissez Faire & 29 & 34,9 \\
\hline \multicolumn{2}{|r|}{ Jumlah } & 83 & $100 \%$ \\
\hline \multirow[t]{2}{*}{3} & - $\quad$ Tidak demokratis & 35 & 34,9 \\
\hline & - Demokratis & 48 & 65,1 \\
\hline \multicolumn{2}{|r|}{ Jumlah } & 83 & $100 \%$ \\
\hline \multirow[t]{3}{*}{4} & - Otoriter & 24 & 28,9 \\
\hline & - Laissez Faire & 19 & 22,9 \\
\hline & - Demokratis & 40 & 48,2 \\
\hline \multicolumn{2}{|r|}{ Jumlah } & 83 & $100 \%$ \\
\hline
\end{tabular}

Sumber: Pengolahan Data Kuesioner, Juli 2019

Menurut Sunyoto (2011) kepemimpinan adalah proses mempengaruhi orang lain untuk memahami dan setuju dengan apa yang harus mereka kerjakan dan bagaimana mengerjakan tugas tersebut secara efektif serta proses untuk memfasilitasi individu dan kelompok untuk mencapai tujuan bersama. Gaya kepemimpinan yang digunakan dalam penelitian ini adalah gaya kepemimpinan menurut Lippits dan K. White yaitu otoriter, demokratis, laissez faire. Berdasarkan hasil penelitian dari penyebaran 
kuesioner kepada 83 perawat pelaksana di ruang rawat inap RS AN-NISA Tangerang didapatkan hasil gaya kepemimpinan paling dominan adalah gaya demokratis yaitu sebanyak $40(48,2 \%)$, sedangkan pada gaya otoriter sebanyak $24(28,9 \%)$ dan gaya laissez faire sebanyak 19 (22,9\%). Hal ini sesuai dengan penelitian yang dilakukan oleh Deniati dan Yanti (2019) bahwa gaya kepemimpinan kepala ruangan di ruang rawat inap RSUD Kota Bekasi paling dominan gaya demokratis sebanyak 47 (78,3\%) sedangkan gaya otoriter $13(21,7 \%)$ dan laissez faire $0(0 \%)$.

\section{Motivasi Kerja}

Tabel 3. Motivasi Kerja di Ruang Rawat Inap RS AN-NISA Tangerang $(n=83)$

\begin{tabular}{rccc}
\hline No. & Motivasi Kerja & Frekuensi & Presentasi (\%) \\
\hline 1. & Kurang baik & 35 & 42,2 \\
\hline 2. & Baik & 48 & 57,8 \\
\hline & Jumlah & $\mathbf{8 3}$ & $\mathbf{1 0 0 \%}$
\end{tabular}

Sumber: Pengolahan Data Kuesioner, Juli 2019

Berdasarkan penelitian yang dilakukan di ruang rawat inap RS AN-NISA Tangerang kepada 83 responden didapatkan hasil bahwa motivasi kerja dalam kategori baik yaitu 48 (57,8\%) dan motivasi kerja dalam kategori kurang baik yaitu 35 (42,2\%). Hal ini sejalan dengan penelitian yang dilakukan oleh Darmayanti (2015) dengan judul Hubungan Motivasi Kerja dengan Kinerja Perawat di Rawat Inap RS Sultan Syarif Mohamad Alkadrie Pontianak bahwa dari 37 responden didapatkan 25 (67,6\%) responden dengan motivasi kerja kategori baik dan $12(32,4 \%)$ responden dengan motivasi kerja kategori kurang baik. Hal ini juga di dukung oleh penelitian yang dilakukan oleh Lestari (2017) dengan judul Hubungan Motivasi Kepala Ruangan dengan Kinerja Perawat di Ruang Dewasa RSUD Kota Yogyakarta didapatkan hasil bahwa dari 40 responden, 31 responden $(77,5 \%)$ motivasi dalam kategori baik dan 9 responden $(22,5 \%)$ motivasi dalam kategori kurang baik. 


\section{Kinerja Perawat}

Tabel 4. Kinerja Perawat di Ruang Rawat Inap RS AN-NISA Tangerang $(\mathrm{n}=83)$

\begin{tabular}{cccc}
\hline No. & Kinerja Perawat & Frekuensi & Presentasi (\%) \\
\hline 1. & Kurang baik & 39 & 47,0 \\
\hline 2. & Baik & 44 & 53,0 \\
\hline & Jumlah & $\mathbf{8 3}$ & $\mathbf{1 0 0 \%}$
\end{tabular}

Sumber: Pengolahan Data Kuesioner, Juli 2019

Menurut Mangkunegara (2005) dalam Saleng (2015) kinerja seseorang dalam bekerja dapat dilihat dari kuantitas dan kualitas yang dicapai oleh seseorang dalam melaksanakan tugasnya sesuai dengan tanggung jawabnya, namun tidak terkecuali dari seorang pemimpin yang dapat memberikan arahan serta menciptakan situasi yang membuat bawahan bahagia dan berhasil dalam melaksanakan tugas. Berdasarkan penelitian yang dilakukan dengan penyebaran kuesioner kepada 83 responden didapatkan hasil kinerja perawat di ruang rawat inap RS AN-NISA Tangerang dalam kategori baik yaitu $44(53,0 \%)$ dan kinerja perawat dalam kategori kurang baik yaitu 39 $(47,0 \%)$. Hal ini sejalan dengan penelitian yang dilakukan oleh Sutrisnoputri, et al (2018) dengan judul Hubungan Disiplin Kerja dan Lingkungan Kerja dengan Kinerja Perawat di Ruang Rawat Inap RSUD Telogorejo Semarang didapatkan hasil bahwa dari 80 responden, 45 responden $(56,0 \%)$ kinerja dalam kategori baik dan 35 responden $(44,0 \%)$ 35 responden kinerja kategori kurang baik. 


\section{B. Analisa Bivariat}

\section{Hubungan Gaya Kepemimpinan Kepala Ruangan Dengan Kinerja Perawat}

Tabel 5. Hubungan Gaya Kepemimpinan Kepala Ruangan dengan Kinerja Perawat di Ruang Rawat Inap RS AN-NISA Tangerang $(n=83)$

\begin{tabular}{|c|c|c|c|c|}
\hline \multirow[t]{2}{*}{ Gaya } & \multicolumn{2}{|c|}{ Kinerja Perawat } & \multirow[t]{2}{*}{ Total } & \multirow[t]{2}{*}{ P-Value } \\
\hline & Kurang Baik & Baik & & \\
\hline \multirow{2}{*}{ Laissez Faire } & 6 & 3 & 9 & \multirow[t]{8}{*}{0,033} \\
\hline & $16,7 \%$ & $6,4 \%$ & $10,8 \%$ & \\
\hline \multirow{2}{*}{ Otoriter } & 14 & 10 & 24 & \\
\hline & $38,9 \%$ & $21,3 \%$ & $28,9 \%$ & \\
\hline \multirow{2}{*}{ Demokratis } & 16 & 34 & 50 & \\
\hline & $44,4 \%$ & $72,3 \%$ & $60,2 \%$ & \\
\hline \multirow{2}{*}{ Jumlah } & 36 & 47 & 83 & \\
\hline & $100 \%$ & $100 \%$ & $100 \%$ & \\
\hline
\end{tabular}

Sumber: Pengolahan Data Kuesioner, Juli 2019

Berdasarkan hasil penelitian bahwa mayoritas gaya kepemimpinan yang digunakan oleh kepala ruangan di ruang rawat inap RS AN-NISA Tangerang menggunakan gaya kepemimpinan demokratis dimana penerapan gaya kepemimpinan demokratis menghasilkan kinerja perawat dalam kategori baik sebanyak 34 (72,3\%). Sedangkan penerapan gaya demokratis dengan kinerja kurang adalah 16 (44,4\%). Hasil analisa bivariat dengan menggunakan uji Chi-Square didapatkan hasil p.value=0,033 yang artinya $\alpha<0,05$. Maka dapat diketahui $\mathrm{H}_{0}$ ditolak yaitu adanya hubungan antara gaya kepemimpinan kepala ruangan dengan kinerja perawat di ruang rawat inap RS AN-NISA Tangerang.

Hal ini sejalan dengan penelitian ynag dilakukan oleh Deniati dan Yanti (2019) didapatkan hasil dari uji chi square $0,000<0,05$ berarti terdapat hubungan antara gaya kepemimpinan kepala ruangan dan kinerja perawat di ruang rawat inap RSUD Kota Bekasi. Hal ini didukung oleh penelitian yang dilakukan Idris, et al (2017) dengan judul Hubungan Gaya Kepemimpinan Kepala Ruangan dengan Kinerja Perawat dalam Melaksanakan Asuhan Keperawatan di Ruang Rawat Inap RSUD Labuang Baji Makassar 
didapatkan hasil bahwa terdapat hubungan antara gaya kepemimpinan dengan kinerja perawat.

\section{Hubungan Motivasi Kerja Dengan Kinerja Perawat}

Tabel 6. Hubungan Motivasi Kerja dengan Kinerja Perawat di Ruang Rawat Inap RS AN-NISA Tangerang $(\mathrm{n}=83)$

\begin{tabular}{|c|c|c|c|c|c|}
\hline \multirow[t]{2}{*}{ Motivasi Kerja } & \multicolumn{2}{|c|}{ Kinerja Perawat } & \multirow[t]{2}{*}{ Total } & \multirow[t]{2}{*}{ OR } & \multirow[t]{2}{*}{ P-Value } \\
\hline & Kurang Baik & Baik & & & \\
\hline \multirow{2}{*}{ Kurang Baik } & 17 & 16 & 32 & 3,250 & 0,033 \\
\hline & $58,6 \%$ & $29,6 \%$ & $38,6 \%$ & & \\
\hline \multirow{2}{*}{ Baik } & 12 & 38 & 51 & & \\
\hline & $41,4 \%$ & $70,4 \%$ & $61,4 \%$ & & \\
\hline \multirow{2}{*}{ Jumlah } & 28 & 55 & 83 & & \\
\hline & $100 \%$ & $100 \%$ & $100 \%$ & & \\
\hline
\end{tabular}

Sumber: Pengolahan Data Kuesioner, Juli 2019

Berdasarkan Hubungan Motivasi Kerja dengan Kinerja Perawat di Ruang Rawat Inap RS AN-NIS A Tangerang didapatkan hasil bahwa motivasi kerja pada kategori baik menghasilkan kinerja perawat dalam kategori baik sebanyak 38 responden $(70,4 \%)$. Hasil analisa bivariat dengan menggunakan uji Chi-Square didapatkan hasil p.value $=0,019$ yang artinya $\alpha<0,05$. Maka dapat diketahui $\mathrm{H}_{0}$ ditolak yaitu adanya hubungan antara motivasi kerja dengan kinerja perawat di ruang rawat inap RS AN-NISA Tangerang. Hal ini sesuai dengan hasil penelitian yang dilakukan oleh Darmayanti (2015) bahwa adanya hubungan antara motivasi kerja dengan kinerja perawat dengan nilai Sig. 0,001 $<0,05$ di RS Sultan Syarif Mohamad Alkadrie Pontianak. Hal ini sejalan dengan penelitian yang dilakukan oleh Lestari (2017) dengan judul Hubungan Motivasi Kepala Ruangan dengan Kinerja Perawat di Ruang Dewasa RSUD Kota Yogyakarta didapatkan hasil bahwa terdapat hubungan anatara motivasi dengan kinerja perawat di Ruang Dewasa RSUD Kota Yogyakarta dengan nilai p.value uji Kendall tau 0,000<0,05.

Hal ini juga didukung oleh penelitian yang dilakukan Saleng (2015) dengan judul Faktor-Faktor Yang Berhubungan dengan Kinerja Perawat di Ruang Rawat Inap RS Khusus Daerah Provinsi Sulawesi Selatan didapatkan hasil dari uji chi square p.value $0,000<0,05$ berarti ada hubungan antara motivasi kerja dengan kinerja perawat di Ruang Rawat Inap RS Khusus 
Daerah Provinsi Sulawesi Selatan. Menurut Mulianto (2006) dalam Librianty (2018) motivasi kerja adalah dorongan kehendak yang mempengaruhi perilaku tenaga kerja untuk dapat meningkatkan kinerja karena ada keyakinan bahwa peningkatan kinerja mempunyai manfaat untuk dirinya. Motivasi rendah ditimbulkan oleh berbagai sebab yang berakibat pada rendahnya kinerja.

\section{SIMPULAN DAN SARAN}

\section{A. SIMPULAN}

Berdasarkan hasil penelitian di ruang rawat inap RS AN-NISA Tangerang didapatkan kesimpulan bahwa dari 83 responden pada kategori usia sebagian besar responden berada pada rentang usia dewasa awal (26-35 tahun). Pada kategori jenis kelamin sebagian besar responden adalah perempuan. Sedangkan pada kategori pendidikan terakhir sebagian besar berpendidikan Profesi Ners. Lalu pada kategori lama bekerja sebagian besar bekerja > 3 tahun. Selanjutnya variabel independen gaya kepemimpinan kepala ruangan, paling dominan adalah gaya kepemimpinan kepala ruangan demokratis yang digunakan dalam memimpin atau mengkoordinasi perawat pelaksana di ruang rawat inap RS AN-NISA Tangerang. Kemudian pada variabel independen motivasi kerja didapatkan hasil motivasi kerja pada kategori baik. Pada variabel dependen kinerja perawat didapatkan hasil kinerja perawat pada kategori baik.

Dari hasil analisa bivariat menggunakan Chi-Square pada Hubungan Gaya Kepemimpinan Kepala Ruangan dengan Kinerja Perawat di Ruang Rawat Inap RS AN-NISA Tangerang didapatkan hasil p.value=0,033 yang artinya $\alpha<0,05$. Maka dapat diketahui $\mathrm{H}_{0}$ ditolak yaitu adanya hubungan antara gaya kepemimpinan kepala ruangan demokratis dengan kinerja perawat di ruang rawat inap RS AN-NISA Tangerang. Hasil analisa bivariat pada Hubungan Gaya Kepemimpinan Motivasi Kerja dengan Kinerja Perawat di Ruang Rawat Inap RS AN-NISA Tangerang didapatkan hasil p.value=0,019 yang artinya 
$\alpha<0,05$. Maka dapat diketahui $\mathrm{H}_{0}$ ditolak yaitu adanya hubungan antara motivasi kerja dengan kinerja perawat di ruang rawat inap RS AN-NISA Tangerang.

\section{B. SARAN}

\section{Bagi Peneliti}

Diharapkan hasil penelitian ini dapat memberikan wawasan dan cara bagaimana menjadi seorang perawat yang profesional ketika menjadi pimpinan (kepala ruangan) dalam menerapkan gaya kepemimpinan yang sesuai terhadap situasi dan kondisi tersebut.

\section{Bagi Institusi Pendidikan}

Diharapkan hasil penelitian ini dapat menjadi studi literatur atau pembelajaran bagi mahasiswa Universitas Muhammadiyah Tangerang terkait gaya kepemimpinan kepala ruangan, motivasi kerja dan kinerja perawat.

\section{Bagi Tempat Penelitian}

Diharapkan hasil penelitian ini dapat dijadikan bahan evaluasi rumah sakit terkait dengan gaya kepemimpinan kepala ruangan dan motivasi kerja dengan kinerja dari perawat pelaksana untuk dapat mempertahankan maupun meningkatkan kinerja perawat. Pada penelitian ini didapatkan hasil bahwa gaya kepemimpinan demokratis yang paling dominan dan menghasilkan kinerja yang baik dibandingkan dengan gaya kepemimpinan otoriter dan laissez faire. Namun, sebenarnya tidak ada gaya kepemimpinan yang dapat dikatakan paling baik atau buruk harus disesuaikan dengan kondisi yang terjadi pada saat itu. Maka dari itu, kepala ruangan dapat memahami setiap gaya kepemimpinan yang ada seperti otoriter, demokratis dan laissez faire serta dapat menyesuaikan dengan situasi dan kondisi. Pada motivasi kerja pertahankan kenyamanan dalam lingkungan kerja, tidak lupa untuk saling memberikan motivasi, baik sesama perawat pelaksana, maupun kepala ruangan terhadap perawat pelaksana, karena tanpa disadari motivasi dapat memberikan pengaruh positif kepada kinerja seorang perawat. 


\section{Bagi Peneliti Selanjutnya}

Diharapkan hasil penelitian ini selanjutnya dapat memberikan informasi terkait gaya kepemimpinan dan motivasi kerja dengan kinerja perawat. Selanjutnya dapat dikembangkan dengan menambah variabel seperti stress kerja, supervisi, dan sistem penghargaan sehingga dapat menjadi tolak ukur maupun bahan evaluasi untuk menilai kinerja dari seorang perawat di ruang rawat inap RS AN- NISA Tangerang.

\section{RUJUKAN}

Calundu, R. 2018. Manajemen Kesehatan. CV Sah Media: Makassar.

Darmayanti, R. 2015. Hubungan Motivasi Kerja dengan Kinerja Perawat Rawat Inap di RS Sultan Syarif Muhamad Alkadrie Pontianak. Skripsi. Program Studi Keperawatan Universitas Tanjungpura. Pointianak.

Deniati dan Yanti. 2019. Hubungan Gaya Kepemimpinan Kepala Ruangan terhadap Kinerja Perawat Pelaksana di Ruang Rawat Inap RSUD Kota Bekasi. Malahayati Nursing Journal (1)1:94-95.

Idris., et al. 2017. Hubungan Gaya Kepemimpinan terhadap Kepala Ruangan dalam Melaksanakan Asuhan Keperawatan di Ruang Rawat Inap RSUD Labuang Baji Makassar. Jurnal Ilmiah Kesehatan Diagnosis (11)3:258

Kepmenkes RI Nomor.857/Menkes/SK/IX/2009 Tentang Pedoman Penilaian Kinerja Sumber Daya Manusia Kesehatan Di Puskesmas. Menteri Kesehatan, Jakarta. 
Lestari, D. 2017. Hubungan Motivasi Kepala Ruangan di Ruang Dewasa RSUD Kota Yogyakarta. Skripsi. Program Ilmu Keperawatan Universitas Aisyiyah. Yogyakarta

Librianty, N. 2018. Hubungan Motivasi dengan Kinerja Perawat Pelaksana di UPTD Kesehatan Tapung Kab. Kampar. Jurnal Ners Universitas Pahlawan (2)2:6.

Nurhidayah. 2018. Faktor-Faktor Yang Berhubungan Dengan Kinerja Perawat Di Ruang Perawatan RSUD Kota Makassar. Jurnal Ilmiah Kesehatan Diagnosis (12)2

Nursalam. 2011. Manajemen Keperawatan: Aplikasi Dalam Praktik Keperawatan Professional Edisi 3. Salemba Media: Jakarta. 2015. Manajemen Keperawatan: Aplikasi Dalam Praktik Keperawatan Professional Edisi 5. Salemba Media: Jakarta.

Saleng, M. 2015. Faktor-Faktor yang Berhubungan dengan Kineja Perawat di Ruang Rawat Inap RS Khusus Daerah Provinsi Sulawesi Selatan. Skripsi. Program Studi Keperawatan Universitas Islam Negeri Alaudin. Makassar.

Sutrisnoputri., et al. 2018. Hubungan Disiplin Kerja dan Lingkungan Kerja dengan Kinerja Perawat di Ruang Rawat Inap RSUD Telogorejo Semarang. Jurnal Kesehatan Masyarakat (6)1:4 